\title{
Reconsideration of Characteristics of Information-Based Resource
}

\author{
Takeaki WADA ${ }^{\text {a) }}$
}

\begin{abstract}
Business management research in Japan categorizes resources into four categories: people, goods, money, and information. Among these, there has been a strong focus on information-based resources, which are company-specific. The notion that these resources are the basis of competitive advantage and inimitability has been considered the reason that Japanese companies exhibited a high level of international competitiveness in the 1980s. However, Japan's international competitiveness has been declining since the 1990s. In fact, (a) information-based resources include not only information but also the capability to utilize that information, (b) resources with low inimitability are mixed in with information-based resources, and (c) information-based resources exhibit stickiness not to companies but to people and goods. Therefore, information-based resources do not automatically become sources of competitiveness. These facts were not comprehended until the 1980s, because Japanese companies were unconsciously able to accumulate information-based resources with high inimitability through Japanese-style management systems, like the lifetime
\end{abstract}

a) Department of Business Administration, Toyohashi Sozo University, 20-1 Matsushita, Ushikawa-cho, Toyohashi, Aichi, Japan, ta-wada@sozo.ac.jp

A version of this paper was presented at the ABAS Conference 2015 Autumn (Wada, 2015).

(C) 2016 Global Business Research Center. This is an Open Access article distributed under the terms of the Creative Commons Attribution License, which permits unrestricted reuse, distribution, and reproduction in any medium, provided the original work is properly cited. 
commitment system. However, these preconditions for Japanese competitiveness were lost in the 1990s, resulting in an outflow of information-based resources embodied in workers and the decline of Japanese companies' international competitiveness.

Keywords: resource-based view of firms, information-based resource, Japanese management theory

\section{Introduction}

Penrose's (1959) view of a corporation as a pool of resources has since been developed into Wernerfelt's (1984) resource-based view (RBV) of firms. Similarly, in Japanese business management research around the time of formulation of RBV theory, studies based on Penrose (1959) were launched (Yoshihara, Sakuma, Itami, \& Kagono, 1981), and subsequent studies on management have been developed (Itami, 1984; Itami \& Karube, 2004; Itami \& Roehl, 1987, etc.).

Compared with RBV theory as it developed in North America and Europe, a series of studies beginning with Yoshihara et al. (1981) was unique in focusing on information-based resources. "Information-based resources" is a term that includes technology, consumer trust, brand image, control of distribution, corporate culture, and management skills (Itami \& Roehl, 1987). The 1980s were a period of great international competitiveness for Japanese manufacturers. Japanese companies' strength at the time owed to factors such as their advanced manufacturing technologies; reliable quality; the integrated approach to development, manufacturing, and sales; and the corporate culture. Thus, Itami and Roehl's view that information-based resources_-from which spring competitive advantage and inimitability-themselves are 
critical is an extraordinarily convincing one.

However, since the 1990s, the international competitiveness of home appliance makers and other Japanese manufacturers has been called into question. Doubts have also been raised regarding the notion that information-based resources give rise to competitive advantage and inimitability.

As many people have pointed out, one reason Japanese home appliance makers have lost competitiveness is because equipment manufacturers absorbed core technologies; consequently, this technology and expertise became embodied in the manufacturing equipment itself. This equipment was then sold to semiconductor manufacturers in emerging countries, causing Japanese companies to lose their technological advantage. Others claim that engineers who retired or were laid off during the post-bubble recession were subsequently hired by companies in emerging countries, leading to a spillover of technology.

Looking at North American and European companies, we can see that, as was noted by Chesbrough (2003), many companies are gaining competitiveness through open innovation that is not making technology and expertise specific to any one company. As can be seen in IBM's sale of its PC business to Lenovo, companies are buying and selling entire brands, as well as development and production technologies.

The thinking that information-based resources are company-specific and sources of competitive advantage and inimitability is not convincing in the aforementioned cases. Itami and Roehl's (1987) assertion depends on two environmental factors: "Japan" and the "1980s."

This paper reviews the discussion on the characteristics of information-based resources and their significance to business management and then considers the problems to resolve in order to adapt to today's business environment. To this end, Section 2 defines 
what information-based resources are, based on Itami and Roehl (1987), and how they contribute to business management. Building on that, Section 3 suggests some points that need to be corrected, specifically, (1) the fact that distinctions between resources and capabilities are ambiguous; (2) because different types of things are lumped together as information-based resources, classification of information-based resources should be refined further; and (3) although it is argued that information-based resources are difficult to trade and imitate because of their stickiness to people and organizations, but it is necessary to consider stickiness of people and goods to companies separately. Section 4 discusses management for gaining competitive advantage through information-based resources.

\section{Overview of Information-Based Resources}

According to Ogawa (2013), business management research in Japan until the early 1970s primarily consisted of reviews and critiques of translated classical business management theory from North America and Europe. In the late 1970s, a group of researchers from Kobe University and Hitotsubashi University (Yoshihara, Sakuma, Itami, and Kagono) aimed to change this approach by creating a business management theory that originated from Japan. Kagono had been focusing on corporate diversification as a research theme, so the group selected Japanese corporate diversification as their research topic. Their research referenced the diversification research of Rumelt (1974).

Assessing the areas of Western business management research that Japanese studies focused on in the 1970s, a look at Nonaka (1974) and Kagono (1980) shows that they had strong interests in topics such as contingency theory (which was popular in the West at the time), the organizational decision model under uncertainty of Thompson (1967), and the information processing models of March 
and Simon (1958) and Galbraith (1973). For example, below is a quote from Kagono (1980).

On the basis of a literature survey, the author believes that the greatest accomplishment of modern organizational theory is that it has generated an awareness of how organizations adapt to their environments, in particular, how organizations adapt to uncertainty as a system for information processing, and that this provides the most productive analytical perspective on business organizations. (from the preface of Kagono, 1980; emphasis inserted by the author)

When regarding diversification as an adaptive behavior to environmental change surrounding companies, the fact that firms placed in similar environments follow different patterns of diversification requires an explanation. Differences in how information is processed by firms were seen as the factor explaining the different patterns of diversification. Although companies may be placed in the same environment, they may differ in their capability to extract information from that environment and analyze the information internally. Their process for affecting the environment through the transmission of information may also be different, which results in different adaptive behaviors. Deriving from the Penrose (1959) concept of resources, Yoshihara et al. (1981) advanced the term "information-based resources" for the firm-specific information processing capabilities that lead to different patterns of environmental adaptation. ${ }^{1}$ Later, the concept of information-based resources was incorporated into strategic management research by

1 With regard to a focus on firm-specific capabilities for adapting to an environment, the concept of information-based resources can be positioned as the idea prior to the concepts of core competence by Prahalad and Hamel (1990) and dynamic capability by Teece, Pisano, and Shuen (1997). 
Itami (1984) and introduced to the West by Itami and Roehl (1987). ${ }^{2}$

A detailed examination of how information-based resources contribute to business management according to Itami and Roehl (1987) is given as follows.

First, companies' information processing systems are composed of three information flows: environmental information flows, internal information flows, and corporate information flows. Information-based resources include both the channels that handle the flows and the information that is accumulated, circulated, and used within the system.

Environmental information flows enable a company to acquire information from an external environment. Environmental information may include production skills, customer information, or channels for bringing in information.

Internal information flows are information processing flows in a company. Internal information include a firm's ability to manage information; employees' ability to transmit and use information in decision-making; and the management capabilities, corporate culture, morale of workers, and habits and norms of effort that underlie these abilities.

Corporate information flows transmit corporate information externally and work to create an environment that is advantageous to the firm. Corporate information includes corporate reputation, brand image, corporate image, distribution channels, and marketing expertise.

Itami and Roehl (1987) created four categories of corporate resources (people goods, money, and information) and emphasized the importance of information-based resources over the other three resources. Itami and Roehl pointed out that while people, goods, and money are physical resources that a business needs to operate,

2 Itami and Roehl (1987) also use the term "invisible asset" as a translation for "information-based resource." 
information-based resources are needs required to achieve competitive success. Moreover, information-based resources cannot be purchased; they can only be accumulated intentionally and over time in the course of doing business; therefore, such resources can become the source of inimitable competitive advantage.

\section{Problems in the Characteristics of Information-Based Resource}

This section points out problems with the characteristics of information-based resources and their importance in business management, as presented by Itami and Roehl (1987).

\section{Lack of distinction between resources and capabilities}

As was mentioned above, Itami and Roehl (1987) consider information-based resources to be composed of many things. Despite this thought, they do not account for the different characteristics of these things; rather, they treat information-based resources as if they were a set of homogenous items.

The first problem with this is that they do not distinguish between information as a resource and the ability to use that information. In discussing the importance of information-based resources in managing a company, Itami and Roehl (1987) state that the simultaneous multiple use of these resources is possible. As for the characteristics of these resources, the authors assumed them to be information goods, such as brands and technology, for which there are no limitations on use because the marginal cost is zero. At the same time, Itami and Roehl pointed out that overextension, that is, striving to create breakthrough ideas to exceed the level achievable with current information-based resources, is essential to the growth of a corporation. This idea assumes bounded capability of use, as with development and production capabilities, to achieve productivity and quality. 
To summarize the above, information-based resources include conflicting characteristics that allow for unlimited use and those that are limited in their use.

\section{Lack of consideration of heterogeneity in the information-based resources}

The second problem is that in spite of information-based resources including various kinds of resources, differences in the degree of inimitability among them are not considered. Itami and Roehl (1987) state that among the four types of resources (people, goods, money, and information), information-based resources are highly inimitable. However, Barney (2001) noted that resources (four in his case: financial capital, human capital, physical capital, and organizational capital) have varying levels of inimitability, which are determined not by their category but by unique historical conditions, causal ambiguity, social complexity, and institutional factors (patents etc.) that make imitation difficult.

As was pointed out by Fujimoto $(2003,2012)$ and Fukuzawa (2015), layers exist in the capabilities underlying companies' competitiveness, some that can be easily imitated and some that cannot. For example, information-based resources such as explicit technical information and brand names are tradable and imitable. However, information-based resources such as those that Toyota possesses, that is, the manufacturing capabilities acquired through the company's everyday kaizen activities on the production line, as well as its underlying corporate culture, are not tradable and imitable because of their unique historical conditions, causal ambiguity, and social complexity.

Ignoring these degrees of inimitability or assuming that inimitability is generally high is a problem.

\section{Lack of consideration of tradability of information media}

Information cannot exist in and of itself but must be embodied in 
people or goods. Because of the stickiness of information, it is difficult to extract the knowledge of certain individuals and teams within a corporation and to trade information alone (von Hippel, 1994). Itami and Roehl (1987) contended that information-based resources have a high degree of inimitability because of that characteristic.

However, when individuals or teams move to other companies, the information-based resources accumulated within those individuals and teams go with them. In addition, a factory's production equipment and people, as well as the information-based resources embodied in them, can be wholly transferred through the sale of a business unit or a merger and acquisition. The stickiness of information-based resources to people and goods and the stickiness of people and goods to firms as information media are separate issues. The inimitability and tradability of information-based resources should be examined according to factors such as follows: whether or not those information-based resources are constructed by the knowledge of many people or, in other words, whether or not a transfer of only certain individuals necessarily leads to a spillover of knowledge; whether or not those information-based resources are dependent on a given corporate culture or, in other words, whether or not they may function in a different corporate culture; and whether or not product design, development, and manufacturing processes are integral or, in other words, whether or not the outflow of only certain modules to other companies may function.

\section{To the Reformation of Information-Based Resource}

The previous section discussed problems with about the arguments on information-based resources, although such problems do not damage the importance of information-based resources as a concept. 
The background behind Itami and Roehl's (1987) argument that information-based resources are firm-specific sources of competitive advantage will now be examined.

In the 1980 s, most Japanese companies maintained integrated manufacturing processes, ranging from production equipment and components to the finished product. These firms manufactured products with integral product architectures. In addition, throughout the 1980s, Japanese firms were on a growth trajectory and accumulated knowledge internally, which was embodied in their human resources, to which they had made a lifetime commitment. Therefore, people in those days did not need to think about the outflow of technologies embodied in people, production equipment, or components. This is probably why without specific management effort, information-based resources were regarded as inimitable.

However, as noted by Ogawa, Shintaku, and Yoshimoto (2005), modularization of product architecture has made it difficult to hold on to technology embodied in things. Furthermore, after the collapse of the bubble economy in the 1990s, some firms went through a restructuring process of selection and focus. The resulting divestiture of business units and early retirement of employees caused the spillover of technologies embodied in people.

As can be seen from the above, discussions on information-based resources can no longer view these resources as firm-specific sources of competitive advantage, because the implicit assumptions no longer hold true. Conversely, an examination of Japanese business management in the 1980s tells us that information-based resources can become firm-specific sources of competitive advantage if the management selects an integral product architecture, encourages teamwork within the firm, and develops and holds on to its human resources.

Mintzberg, Ahlstrand, and Lampel (2009) position Itami and Roehl (1987) as research belonging to the learning school. It is a problem 
that theories explaining environmental adaptation cannot adapt to environmental change. Research on information-based resources must also "learn" from the changing circumstances starting in the 1990 s, adapt to environmental changes, and remain updated.

\section{References}

Barney, J. B. (2001). Gaining and sustaining competitive advantage (2nd ed.). Upper Saddle River, NJ: Prentice Hall.

Chesbrough, H. W. (2003). Open innovation: The new imperative for creating and profiting from technology. Boston, MA: Harvard Business School Press.

Fujimoto, T. (2003). Nouryoku kouchiku kyousou: Nihon no jidosha sangyou ha naze tsuyoi noka [Capability-building competition: The reason why Japanese automobile industry has competitiveness]. Tokyo, Japan: Chuou Kouron Shinsha (in Japanese).

Fujimoto, T. (2012). Evolution theory of production systems. Annals of Business Administrative Science, 11, 25-44. doi: 10.7880/abas.11.25

Fukuzawa, M. (2015). Competitiveness of Japanese electric and electronics factories. Annals of Business Administrative Science, 14(4), 217-230. doi: 10.7880/abas.14.217

Galbraith, J. (1973). Designing complex organizations. Reading, MA: Addison-Wesley.

Itami, H. (1984). Shin keieisenryaku no ronri: Miezaru shisan no dainamizumu [Theory of management strategy: Dynamism of invisible assets] (New ed.). Tokyo, Japan: Nihonkeizaishinbunsha (in Japanese).

Itami, H., \& Karube, M. (2004). Miezaru shisan no senryaku to ronri [Strategy and logic of invisible assets]. Tokyo, Japan: Nihonkeizaishinbunsha (in Japanese).

Itami, H., \& Roehl, T. W. (1987). Mobilizing invisible assets. Cambridge, MA: Harvard University Press.

Kagono, T. (1980). Keiei soshiki no kankyou tekiou [Environmental 
adaptation of the organization]. Tokyo, Japan: Hakutoushobou (in Japanese).

March, J. G., \& Simon, H. A. (1958). Organizations. New York, NY: John Wiley \& Sons.

Mintzberg, H., Ahlstrand, B. W., \& Lampel, J. (2009). Strategy safari: The complete guide through the wilds of strategic management (2nd ed.). Harlow, UK: Financial Times Prentice Hall.

Nonaka, I. (1974). Soshiki to shijoh: Soshiki no kankyou tekigou riron [Organization and market: Environmental adaptation theory of the organization]. Tokyo, Japan: Chikurashobou (in Japanese).

Ogawa, K., Shintaku, J., \& Yoshimoto, T. (2005). Architecture-based advantage of firms and nations: New global alliance between Japan and catch-up countries. Annals of Business Administrative Science, 4, 21-38. doi: 10.7880/abas.4.21

Ogawa, S. (2013). Nihon keieigaku no inobeshon: Daiikkai kunkogaku kara jisshoukenkyuuhe [Innovation in Japanese management research: Part 1, from the literature research to experimental study]. Hitotsubashi Business Review, 60(4), 164-167 (in Japanese).

Penrose, E. T. (1959). The theory of the growth of the firm. Oxford, UK: Oxford University Press.

Prahalad, C. K., \& Hamel, G. (1990). The core competence of the corporation. Harvard Business Review, 68(3), 79-91.

Rumelt, R. P. (1974). Strategy, structure and economic performance. Cambridge, MA: Harvard University Press.

Teece, D. J., Pisano, G., \& Shuen, A. (1997). Dynamic capabilities and strategic management. Strategic Management Journal, 18(7), 509-533.

Thompson, J. D. (1967). Organizations in action: Social science bases of administrative theory. New York, NY: McGraw-Hill.

von Hippel, E. (1994). "Sticky information" and the locus of problem solving: Implications for innovation. Management Science, 4O(4), 429-439.

Wada, T. (2015, November). Information roles in Japanese management theory. Paper presented at ABAS Conference 2015 Autumn, University of Tokyo, Japan.

Wernerfelt, B. (1984). A resource-based view of the firm. Strategic 
Management Journal, 5, 171-180.

Yoshihara, H., Sakuma, A., Itami, H., \& Kagono, T. (1981). Nihon kigyouno takakuka senryaku: Keiei shigen apurochi [Diversification strategies of Japanese firms: Approaching from resource view]. Tokyo, Japan: Nihonkeizaishinbunsha (in Japanese). 